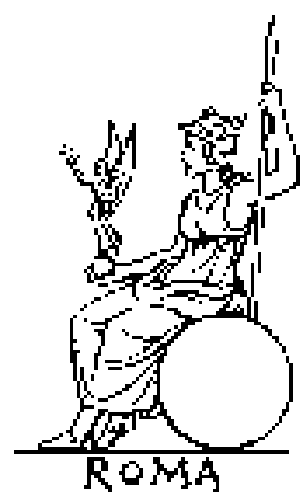

Confarreatio: A Study of Patrician Usage

Author(s): W. Warde Fowler

Source: The Journal of Roman Studies, Vol. 6 (1916), pp. 185-195

Published by: Society for the Promotion of Roman Studies

Stable URL: http://www.jstor.org/stable/296271

Accessed: 18/08/2013 14:17

Your use of the JSTOR archive indicates your acceptance of the Terms \& Conditions of Use, available at http://www.jstor.org/page/info/about/policies/terms.jsp

JSTOR is a not-for-profit service that helps scholars, researchers, and students discover, use, and build upon a wide range of content in a trusted digital archive. We use information technology and tools to increase productivity and facilitate new forms of scholarship. For more information about JSTOR, please contact support@ jstor.org. 


\section{CONFARREATIO: A STUDY OF PATRICIAN USAGE.}

BY W. WARDE FOWLER.

In his first book Gaius writes of manus, and begins by telling us that while potestas is exercised over both males and females, women alone come under manus. Then he goes on to say that in old times there were three ways in which women could come under manus, viz. usu, farreo (or confarreatione) and coemptione : and proceeds to explain these three. It will be convenient for my purpose if I quote his explanations in full :

Sec. III. Usu in manum conveniebat quae anno continuo nupta perseverabat; quia enim velut annua possessione usucapiebatur, in familiam viri transibat filiaeque locum optinebat. Itaque lege duodecim tabularum cautum est, ut si qua nollet eo modo in manum mariti convenire, ea quotannis trinoctio abesset, atque eo modo [usum] cuiusque anni interrumperet. Sed hoc totum ius partim legibus sublatum est, partim ipsa desuetudine oblitteratum est.

Sec. II2. Farreo in manum conveniunt per quoddam genus sacrificii quod Iovi farreo fit, in quo farreus panis adhibetur : unde etiam confarreatio dicitur. Sed conplura praeterea huius iuris ordinandi gratia cum certis et solemnibus verbis, praesentibus decem testibus aguntur et fiunt. Quod ius etiam nostris temporibus in usu est ; nam flamines maiores, id est Diales Martiales Quirinales, item reges sacrorum, nisi ex farreatis nati non leguntur; ac ne ipsi quidem sine confarreatione sacerdotium habere possunt.

Sec. II3. Coemptione vero in manum conveniunt per mancipationem, id est per quandam imaginariam venditionem; nam adhibitis non minus quam $V$ testibus civibus Romanis puberibus, item libripende, emit mulierem [is] cuius in manum convenit. (Ed. Krueger-Studemund, I 89I).

An anthropologist and a lawyer might read these passages with different feelings. The lawyer, looking for the legal result of ancient Roman marriage, as Gaius does himself, puts usus, confarreatio and coemptio into the same category, because they all produce the legal result that the bride passes under the manus of her husband. And as Roman lawyers have always abounded, while anthropology is a modern science, the student of Roman antiquities has usually been led to believe that usus, confarreatio and coemptio were ' the three modes of ancient Roman marriage.' He might also qucte Servius on Georgic i, 31, who writes: Tribus modis apud veteres nuptiae fiebant, and proceeds to describe usus, confarreatio and coemptio in 
language which I shall have to refer to later on. Servius was quite right up to a certain point; all these three processes were at one time necessary, i.e. one or other of them, to a legal patrician marriage, because manus was originally necessary to the complete legal relation between a patrician and his wife; but he was mistaken in supposing -if he did suppose it-that usus and coemptio were in theniselves sufficient to constitute true marriage. A religious ceremony was also necessary, of which he says nothing. ${ }^{1}$ At no time in Roman history was true marriage possible without auspice, sacrifice, and other rites which belong to the region of religion. These religious forms are familiar to us in the later Roman marriage, and there can be no doubt that they were also in use in the early forms which produced manus. ${ }^{2}$

The anthropologist, on the other hand, sees at once that of the three forms described by Gaius, confarreatio stands by itself, on quite a different footing from the two others. It is a religious ceremony which has the legal result of producing manus, while the other two, though they produce manus, are in no sense religious ceremonies. They are used in other Roman legal processes which have nothing to do with marriage; coemptio, for example, which is an imaginary sale, can be used for the conveyance of a filiusfamilias by his father for certain legal purposes. As Gaius says in sec. II4, there are two forms of coemptio, matrimonial and fiduciary; in the latter case the woman is conveyed to a stranger, e.g. for liberation from guardianship. Confarreatio, however, is not a mere legal process, and can be used for no other purpose but marriage, and marriage within that higher social class known to us as patrician. Even religiously it differs from other forms, inasmuch as the presence of State priests was necessary in it. Its most peculiar feature is not found in the later ceremonial of Roman marriage, and from the fact that the features of that ceremonial are not mentioned in our accounts of confarreatio, we may infer that the latter was at all times distinct, and is to be treated independently of other forms of Roman marriage. ${ }^{3}$

It seems worth while to study it afresh in the light of comparative religion and anthropology; for during the last few years the history of human marriage has been the subject of several important works. Apart from books of a general kind, such as Frazer's Golden Bough or

${ }^{1}$ See Cuq, Institutions juridiques des Romains, p. 208. "Il faut reconnaitre que la loi s'est abstenue de poser des règles sur la formation du mariage ... La loi s'est bornée à établir certaines solennités qui peuvent s'ajouter aux cérémonies ordinaires du mariage et qui lui font produire des effets particuliers." I believe this to be the right account.

2 The distinction between marriage and manus is best brought out by E. Cuq, op. cit. p. 206 foll. On the subject of confarreatio generally, Rossbach's Römische Ebe is the foundation of most modern work on the subject; Marquardt, Privatleben, p. 27 foll.; De Marchi, La Religione nella vita domestica, p. I45 foll.; art. 'Matrimonium,' in Daremberg-Saglio's Dictionnaire. The article in Pauly-Wissowa on 'Confarreatio' does not seem to me an improvement on that of Rein in the old edition of Pauly. All comprehensive works on Roman law of course deal with the subject of marriage more or less closely.

${ }^{3}$ Dionysius of Halicarnassus saw this quite clearly; in 2,25 he calls confarreatio the sacred form of marriage as compared with the other two. 
Westermarck's history of Human Marriage, we have recently had the latter author's work on marriage in Morocco, Mr. Crawley's Mystic Rose (a book which I have found more instructive than the rest), and Mr. Hartland's Primitive Paternity. All of these refer more than once to the Roman confarreatio, but without special knowledge of things Roman. I wish to examine it not only as a curious specimen of antique ceremonial, but in relation to the development of Roman society from very primitive material.

It is not easy to form a clear idea of this ceremonial. Fortunately we know two or three remarkable features of it, which were probably the most important ones ; but we are expressly told by Gaius that there were many others, and of these we know nothing. We should much like to know where it took place; but this is only matter of conjecture. Some have supposed that it was in the private house of bride or bridegroom, or in both, as in the wedding of historical times. ${ }^{1}$ But I entirely agree with Marquardt that the presence of great State priests, the Pontifex maximus and flamen Dialis, gave the rite a distinctly public character, inconsistent with the privacy of a family residence. ${ }^{2}$ The marriage by confarreatio had in fact an object at once social, political, and religious; it was an alliance between families and their sacra, and it was also the special means of providing children capable of doing good service ' in Church and State.' For in order to be eligible for the great priesthoods, the flamines maiores and the rex sacrorum, or even to serve as acolytes (camilli, camillae) in their early years, children must be born of a marriage celebrated by confarreatio. This is the proper meaning in Roman ius divinum of pueri patrimi et matrimi, ${ }^{3}$ though in late times it was taken to mean, as it is now generally understood, children whose parents were both living. We must be perfectly clear as to this object of confarreatio; it was a ceremonial of the most vital importance for the welfare of the State.

It will be as well, before going on to the special features of the rite, to say a word about the two priests who were essential to it, and their significance in regard to it. The Pontifex maximus was not, I imagine, a principal in the rite until the kingship had come

1 Marquardt, Privatleben, 34 , note 4 .

2 Marq. ib. His view has been largely adopted in place of the older one of Rossbach and Rein, e.g. in Daremb.-Saglio (article by L'Écrivain).

3 This is distinctly stated by Servius (Interpolator) Georg. i, 3I : 'ex quibus nuptiis (i.e. by confarreatio) patrimi et matrimi nascebantur.' If the commentator is right here, the importance of the words is obvious. No doubt it was also necessary that these boys and girls should be the children of living parents, according to a rule more familiar to us in Greek ritual; and thus the idea arose that this was the sole or primary meaning of the words patrimi et matrimi (so in Festus, s.v.
Flaminia, p. 82, Lindsay; cp. I I3). In ancient times no doubt the camilli and camillae would be the children of the priest on whom they attended. But as that rule had to be relaxed for obvious reasons, it was necessary to make sure that those children chosen for the work had the same qualification of birth as the flamen and his wife, i.e. were born of a marriage by confarreatio: then, too, the question of living parents came up for the first time. When Horace (Carm. iv, 6, 3I) is speaking of the children whom he was training for the performance of his Carmen saeculare (children who were of course patrimi et matrimi), he writes ' virginum primae puerique claris patribus orti.' 
to an end; he here represents the Rex of an older time, as he did in other ways. He probably combined auspicium and imperium, as the Rex alone had done while the office remained, and among the later magistrates those only who were in direct descent from the Rex. His presence therefore strongly suggests that a marriage by confarreatio was of importance to the whole community, and not merely one way of transferring a bride from one family and its sacra to another. What part he took in the rite we do not know for certain; but he was a guarantee, together with the ten witnesses, ${ }^{1}$ that all was done in order and according to ancient tradition, and all formulae correctly spoken.

The flamen Dialis on the other hand represented not man but god; the god who was the guide and protector of the race long before it settled in Latium. The taboos to which this flamen was subject carry him back to the age of stone, when men roasted the grain which they had previously ground with pestle and mortar ${ }^{2}$; when iron and yeast were unknown. The further we go back in Roman antiquities, the more prominently does this god stand out, the more pregnant with meaning he seems to be ; the later supremacy of the Jupiter of the Capitoline trias can only be understood if we assure ourselves that a namesake of his had been the leading deity of this stock since it settled in Italy, and probably long before that era. His goodwill was the essential guarantee for the continuity of the community and all its divisions; and especially in all social co-operation, in all transactions calling for fides, good faith, in all dealings with other communities under the fetial law, he is the paramount protecting influence. Now marriage is a contract; and confarreatio was a contract not only in a legal sense but in a religious one also. No wonder then that the priest must be present who (with his wife) was charged with the maintenance of the ' peace,' the covenant of goodwill, between the deity and this group of his worshippers; and who perhaps in some sense, about which it is best not to be too precise, represented that deity in his sacred precious person. ${ }^{3}$

Thus the presence of the Pontifex maximus and of the flamen of Jupiter is sufficient proof that confarreatio was a public and not a private ceremony ; from which it seems to follow that it must have taken place in a public and not a private building. The difficulty here is that in the early ages of Italian religious life there were no temples properly so called, not indeed till long after the permanent

\footnotetext{
1 These ten witnesses, of whom Gaius is careful to tell us, have occasioned a good deal of trouble and speculation. Many have held that they represented the ten curiae of the tribe to which the parties belonged. The view of the writer in Daremberg-Saglio is that they represented the ten gentes of the curia to which the parties belonged.
}

But the number ten is so usual in matters of administration all through Roman history that it is perhaps needless to indulge in speculation on meagre data.

${ }^{2}$ See Peet, Stone and Bronze Age in Italy, p. 362 foll.; Roman Festivals, p. I49, note 3 .

${ }^{3}$ See my Roman Ideas of Deity, lecture ii. 
settlement in Latium. Hence scholars have had to fall back on e.g. the house of the bride, as I mentioned above. But Marquardt has made a suggestion which seems to me to suit both the facts as far as we know them, and the probabilities of the case, viz. that the scene of the wedding was the religious centre of the curia to which one or both of the parties belonged. ${ }^{1}$ This centre was also called curia, in the sense of a house or hall, where meetings for various purposes could be held. The thirty curiae into which the whole people was divided-originally of course the patricians only-had each its religious house as a centre-point of its religious, military and agricultural activity.. Why both the division and its centre should have the same name has long been a puzzle, complicated by a delusion that the word curia was etymologically connected with Juno Quiritis, Quirites, etc. I have myself a strong conviction, which I will merely mention here, that the word in both senses should be traced back to the period of the pile-dwellings and the later terremare of north Italy; when the rectangular long house, built on and supported by a platform on piles, like the long house of the Borneo of to-day, ${ }^{2}$ was the centre of the population and the agriculture of a considerable number of families. Though not constituting an independent community itself, it was probably one among others which together did so constitute one. Such a 'house' in Borneo has a chief of its own, subordinate to the chief of the whole tribe, and answers much more closely to the Roman curia than to eht gens (in spite of the writer in Pauly-Wissowa ${ }^{3}$ ), as being a political division of the tribe, and yet at the same time a building in which all the business of that division was transacted. The building survived in later Roman times as a centre point which had lost its old double significance ; for in the course of migration and settlement, as the late Prof. Pelham reminded us in treating of the curia, ${ }^{4}$ modifications take place in institutions which make it often difficult to trace them back to their true sources.

The first act in confarreatio was apparently the sacrifice of a sheep, as we know that at the marriage of the flamen himself ${ }^{5}$ the skin of a sheep was used directly afterwards in a peculiar way, as we shall see. 'To what deity was it offered? As the flamen Dialis was always present, and as Jupiter is the deity chiefly concerned,

\footnotetext{
1 Privatleben der Römer, p. 34. Prof. Reid suggests the Regia, which to me seems less likely.

${ }^{2}$ See my paper, 'Ancient Italy and Modern Borneo,' F.R.S. I916, p. I4.

3 There is no real evidence that the curia was at any time a division of kinship; the gens on the other hand was such theoretically if not in actuality. The curia was a military and territorial division, also used for political purposes, with a centre point in the form of a house. Pelham's description, in his Essays on Roman History, p. 4 foll. (cp. 9), is accurate and useful, though his
}

theory has not met with approval, and his recent reading of Stubbs's Constitutional Hist. of England, vol. $\mathrm{i}$, had biased him in favour of an origin too entirely military.

${ }^{4}$ ib. p. 7 .

${ }^{5}$ Mos enim apud veteres fuit Flamini ac Flaminicae ut per farreationem in nuptias convenirent, sellas duas iugatas ovili pelle superiniecta poni, eius ovis quae hostia fuisset, et ibi nubentes velatis capitibus in confarreatione Flamen ac Flaminica residerent: Servius (Interp.) ad Aen. iv, 374. 
there can barely be a doubt that Jupiter here was the deity-the great god of the Latin stock, the father of his people, whose interests were bound up with the continuance of his race. The sheep was not the victim we usually associate with him; but we may remember that on the ides of every month this same flamen offered him a sheep (ovis idulis) on the Capitol, and may conclude that the white heifer (iuvencus) was reserved for the greater festivals of the ides of September and the feriae Latinae. All weddings, as I have said, were accompanied with a sacrifice: 'apud veteres neque uxor duci neque ager arari sine sacrificiis peractis poterat' (Interpol. Serv. Aen. iii, I36). This is a comment on the line which describes the Trojans busy on the coast of Crete, 'connubiis arvisque novis operata iuventus,' which is taken in a religious sense; and whether the commentator be right or wrong, the parallel between marriage and ploughing is well known to anthropologists. Each involved the breaking of new ground, the beginning of a new state of things; and it was necessary to secure and ascertain the will of the god concerned. I find this point curiously illustrated, and in a way specially interesting for our present subject, in Mr. Crooke's Folklore of Northern India, i, I92 :

'Among some castes the polished ploughshare is fixed up in the marriage shed during the ceremony. Among the Craons, the bride and bridegroom are made to stand on a curry stone, under which is placed a sheaf of corn resting on the plough yoke, and among the same people their god Darha is represented by a ploughshare set upon an altar dedicated to him. Here we have the mystic influence of grain and iron combined with the agricultural implement fetish.'

But I must not wander too far from Rome.

Next came what seems to us the most remarkable feature of the whole rite; but the exact order of procedure, it must be granted, is not matter of certainty. The skin of the sacrificed sheep was placed upon two sellae or stools, so as to cover them, leaving no space between (sellas duas iugatas ovili pelle), and on these the pair had to sit with veiled heads ' in confarreatione,' i.e. (as I take it), while the sacrament of the cake was administered to them, as we shall see directly. The object or meaning of this can no longer be in doubt, since the recent researches already mentioned have opened up the whole question of marriage ritual. In his work, The Mystic Rose, Mr. Crawley has fully examined the mysteries of sexual taboo, and explained it in his seventh, eighth and ninth chapters. He has shown that so far from recklessness or promiscuity in sexual matters being a feature of primitive life, the exact opposite is the truth. In this sphere, as in that of food, both of them so vital to the interests of humanity, we find a system of rigid taboo, based on mysterious instincts of doubt or awe.

Now what we call marriage was originally the method of breaking 
this taboo without damage to the parties concerned-an object only to be achieved by solemn magical or religious rites. The idea that all contact of man and woman is dangerous forced men to devise a plan for counteracting such danger. "The ceremonies of marriage are intended to neutralise these dangers, and to make the union safe, prosperous, and happy. With this is connected the wish to bind the one to the other, so as to prevent, if possible, later repudiation.' 1 Some of these ceremonies consist in a kind of mutual inoculation, both parties being subjected to the same process; and this is the class to which the Roman rite belongs. 'They sit together on the victim's skin, a thing extremely ' holy,' as we know well from many other uses to which it is found applied; with this holiness, it would seem, they both become inoculated at the same moment, with the result that the old taboo, with all its doubts and fears, vanishes as between them, while at the same time they are rendered all but incapable (as we shall see directly) of subsequent separation. The union with the magic power of the fleece both permits and secures the union of bride and bridegroom. The well-known practice of sleeping on the hide of a slain victim in divination, must have had an object of the same kind. ${ }^{2}$ How exactly the magic was supposed to work in each case it is probably impossible to discover; but we can get as far as this, that by wearing, or by sleeping, standing, or sitting on, the skin of a victim, admission was effected to some form of union with the deity to whom the victim was offered, and that if two persons took part in the process, they were themselves mystically united. The union was further confirmed and expressed by the administration to each of the pair of a cake of far, made no doubt by pounding and roasting according to ancient fashion, and offered at the same time sacrificially to Jupiter, who here took the cult-title of Farreus, ${ }^{3}$ as in the worship of the farm he took that of Dapalis; it was doubtless accompanied by a prayer, and he who will may find a pattern for this in the prayer to Jupiter Dapalis given by Cato in the I3Ist chapter of his book on agriculture. 'The highly religious character of this part of the ceremony is in one way the most difficult point to explain. Nothing of course is commoner in marriage rites than that the pair should partake of the same food, and the reader has only to turn to Mr. Crawley's work already quoted to find plenty of examples of the custom, which plainly means that the ancient taboo is broken forbidding the two sexes to eat together. ${ }^{4}$ But among these examples I can hardly find one in which the thing eaten is also regarded as a sacrifice to a deity. When in Celebes we read

${ }^{1}$ Crawley, Mystic Rose, p. 320, and the whole of chapter xiv.

${ }^{2}$ See Halliday's Greek Divination, I32; R. Smith, Religion of the Semites, 417; Pley, de lanae in antiquorum ritibus usu, p. I5; Samter, Familienfeste, roo foll.
${ }^{3}$ See the text of Gaius I I2, quoted above, p. I. Prof. Reid tells me that he takes farreo here not as a cult-title. but as abl. of farreum. But if so, why does Gaius think a further explanation necessary-'in quo farreus panis adhibetur'?

${ }^{4}$ Mystic Rose, p. 378 foll. 
of the pair sitting on the same mat and eating together, we are reminded of the skin and the cake in confarreatio, but the sacred character of the latter is not there. And it is just this extreme holiness that is the most interesting point in our problem.

This impression of the highly religious character of this marriage is increased if we turn to Servius on Georg. i, 3 I (here it is the Interpolator, who seems to have been well informed), and note that the cake of far, or mola salsa as it was called in the religion of the State, was accompanied with fruges. The combination was one of high religious antiquity; Pliny ascribed it to Numa, ${ }^{1}$ a pretty sure sign of Roman belief that a rite was ancient. 'Numa instituit deos fruge colere et mola salsa supplicare, atque, ut auctor est Hemina, far torrere.' Fruges accompany other sacrifices in the ancient ritual of the Fratres Arvales, and in that of the ludi saeculares; we find them also used at the foundation of a city, and at the annual festival of the boundary-stone (Terminus). It would be easy to follow up this point still further, and to connect these fruges with the

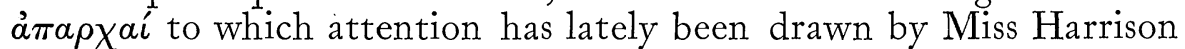
and Mr. Cornford ${ }^{2}$; but this would take us too far afield.

The two chief facts then in confarreatio were the use of the skin of the sacrificed sheep, and the administration of the sacramental cake, together with fruges. Apart from these we have no details which can be clearly distinguished from those of the ordinary Roman marriage of historical times. But we are told by Gaius that many other things were done 'cum certis et solemnibus verbis,' and by the verba here we must understand carmina or spells, which would yet further increase the firmness of the bond created when once the taboos were overcome, and make it difficult or impossible to break it. For divorce after confarreatio was, to say the least of it, extremely rare, and if it were not for the word diffarreatio we might reasonably doubt whether it was possible, seeing that we do not hear of a case till the empire. Plutarch, however, in a Roman question (no. 50) gives some account of it, and as the case which attracted his attention to the subject occurred in his own time, we have some reason for trusting him. This was the divorce of a flamen Dialis, at which other priests were present, and performed many strange and awful ceremonies. Festus, that is, Verrius Flaccus, knew the word diffarreatio, but only tells us that cakes of far were here also used. Gellius tells us that the marriage of the flamen was indissoluble, and Dionysius seems to say the same of all marriages by confarreatio. 3

\footnotetext{
1 Plin. N.H. xviii, 7 .

${ }^{2}$ Essays and Studies presented to William Ridgeway, p. 153 foll. ; Harrison, Themis, p. 306 foll.

${ }^{3}$ Festus (Lindsay), p. 65; Gell. x. 1.5: Matrimonium flaminis nisi morte dirimi ius non est. So Dionys. ii, 25. The available evidence
}

seems to show that among primitive peoples divorce is more difficult the higher the social position of the married pair; in other words, the more 'holy' or precious they are, the less easy it is to break a bond once solemnly consecrated: Westermarck, Hist. of Human Marriage, p. 535. In India the 
This brings me in the last place to a question at once important and difficult. Were all patricians originally married by these solemn rites, which needed the presence of the Rex or Chief of the community, of the priest of Jupiter, of ten witnesses, and consisted of sacrifice, sacrament, and special forms of prayer or spell ? Or was confarreatio, as I have described it, a specially solemn form of marriage for certain religious purposes? Servius, or rather his Interpolator, causes us much difficulty here. I have so far been assuming that our two chief features, the use of the victim's skin and the sacramental use of the cake of far, were both of them part of all marriages by confarreatio. Unluckily there is a certain amount of doubt about this, for the Interpolator, usually well informed, seems to believe that the use of the skin belonged only to the marriage of the flamen and flaminica. ${ }^{1}$ Twice over he mentions this pair as subjected in wedlock to these processes, in such a way as to preclude the notion of other marriages having the same ritual; and in another note he alludes to this marriage of the flamen as being part of the ius pontificium. But there is a difficulty here which the commentator has not explained. Before the flamen Dialis could take up his office, it is almost certain that he must be already married; he and his wife were both in the solemn service of Jupiter, which could not be carried on without both of them, and if the flamen lost his wife, he himself was obliged to resign his office. ${ }^{2}$ As it was the usual practice among the Roman nobility to marry young, we may be pretty sure that the flamen and flaminica came into office together, and had probably known for some time past what might be going to happen to them; for no doubt the pontifices kept a list of those who were eligible, out of whom three were selected (as Tacitus tells us) as candidates for the final choice. ${ }^{3}$ If the candidate finally chosen was not already married, it would seem that he would at once take a suitable wife; when Julius Caesar was so selected at the age of sixteen, he repudiated his betrothal to an equestrian young lady (perhaps because her parents had not been married by confarreatio) and married the daughter of the patrician consul Cornelius Cinna. ${ }^{4}$ Here we must presume that Caesar's father and Cinna were both married by confarreatio.

But it must have often happened that the selected person had been married some time; the appointment of boys like Caesar must

higher castes rarely divorce, ib. 525. Thus we can well understand how the flamen, having religious duties in common with his wife, could not legally divorce her; and we may take it that the case mentioned by Plutarch $(Q . R .50)$ was an innovation. The sacerdos confarreationum et diffarreationum of C.I.L. x, 6662 (Dessau, Inscr. Lat. Sel. I455) seems to be of the age of Commodus.

1 ad Aen. iv, 374: Mos apud veteres fuit Flamini et Flaminicae ut per farreationem in nuptias convenirent, sellas duas iugatas ovili pelle superiniecta poni, eius ovis quae hostia fuisset, et (ut) ibi nubentes velatis capitibus in confarreatione Flamen et Flaminica residerent. $\mathrm{Cp}$. the same commentator on iv. 103 : 'farreatas nuptias, quibus Flaminem et Flaminicam iure pontificio in matrimonium necesse est convenire.' Gaius, i, I I 2 ad fin.

${ }^{2}$ Gell. x, I 5, 22 ; Frazer, Adonis, Attis, Osiris, ed. $z$, appendix ii.

3 Tac. Ann. iv, 16.

${ }^{4}$ Suet. $\mathcal{F} u l$. i init. 
have been exceptional. In that case the Servian Interpolator must have meant, when he said that flamen and flaminica were married by special solemn rites, that before they entered on office they were re-married in some special way. ${ }^{1}$ And from all we know of the relations between the two, and the solemn nature of their life and duty, I think this is highly probable. The two must be united as no other pair were united, in order to be devoted to the service of the great deity; and I conjecture that this form of union included the rite of the victim's skin, which did not take place on ordinary occasions. If this were so, perhaps the albogalerus, the head-dress of the flamen, or at any rate the first one he wore during his office, was made of this victim's skin. Here we have the evidence of Varro to help us: Is (i.e. flamen Dialis) solum album habet galerum, vel quod maximus, vel quod Iovi immolata hostia alba id fieri oporteat. ${ }^{2}$

On the whole there is a good deal to be said for this view, i.e. that flamen and flaminica had to be married or re-married by a rite of special solemnity immediately before taking up their sacred office. But in this case are we to give up the curious rite of the two sellae and the victim's skin as a part of the ordinary confarreatio ? We cannot be certain, but I am inclined to think it safer to do so. I think it possible that there has been a confusion between this and the use of a skin, not necessarily a victim's, in the ordinary Roman marriage. 'In pelle lanata nova nupta consedere solet, vel propter morem vetustum, quia antiquitus pellibus homines erant induti, vel quod testetur lanificii officium se praestaturam viro.' This gloss of Festus (Lindsay, I02) may mean only that the bride sat on such a skin when first installed in her husband's house; but it reminds us of many customs of marriage, such as the sitting on a mat together, which have no such mystical meaning as the use of the victim's skin for a similar purpose; and it makes me still more inclined to consider that solemn and apparently indissoluble rite as belonging only to the initiatory ceremony of the flamen Dialis and his wife. As this flamen had to be present at all marriages by confarreatio, and to be in some way the mediator between Jupiter himself and the couple to be married, it would seem natural that in his own marriage (or re-marriage) there should be a ritual of even greater mystical and magical significance.

Supposing then that we think of the ordinary confarreatio as being minus this mystical ritual of the sacrifice and skin, and consisting only in the offering of a sacred cake to Jupiter and the sacramental

\footnotetext{
${ }^{1}$ Possibly Gaius was thinking of this when he wrote (i. Ir2 ad fin.) ' ac ne ipsi quidem sine confarreatione sacerdotium habere possunt.'

2 Marquardt, Staatsverwaltung, iii, 330 , note $\mathrm{r}$. Varro's words, from his second book Rerum divinarum,
}

are quoted by Aulus Gellius, x, I 5, 32. Samentum was the name at Anagnia of the head-dress of a flamen made of a victim's skin. See Fronto, ed. Naber, p. 67 r. 
eating of it by bride and bridegroom, are we to conclude that this was originally the common form of patrician marriage ? Let us note that even without the skin-rite, it was a highly religious form, as Dionysius expressly described it. I take it that it was at least necessary for all chiefs and their families, who would be called on to supply children, patrimi et matrimi, qualified to carry on the duties of worship and propitiation necessary to secure the pax deorum for the whole community. That the patriciate in this limited sense, together with the flamen Dialis and confarreatio, existed before the settlement in Latium, I have personally no doubt whatever; but I can only guess that after that settlement, with the inevitable increase in the number of worships, the number of families needed to supply children for religious duties would naturally increase in proportion.

My conclusion, which is simply a hypothesis founded on an often renewed examination of what we know about confarreatio, may be thus stated. There were two kinds or grades of confarreatio: or to put it perhaps more exactly, the same name in historical times covered two originally distinct rites: (I) the ordinary patrician rite which took its name from the cake of far-the most important element in the process; and (2) a specially solemn rite, applicable only in the case of the flamen Dialis and the flaminica his wife, who, though usually married already, had to go through this in order to qualify for their holy office. This specially solemn rite involved, among other ceremonies of which we know nothing, that use of a victim's skin which is now well known to indicate extreme religious holiness. 